PROBLEMS

OF MANAGEMENT

IN THE $21^{\text {st }}$ CENTURY

Volume 3, 2012

\title{
PLANNING AS THE BASIC FUNCTION OF TOURISM AND RECREATION MANAGEMENT IN POLAND
}

\author{
Izabela Kapera \\ University School of Physical Education in Cracow, Poland \\ E-mail: lowczowska@poczta.onet.pl
}

\begin{abstract}
The subject of this article research are issues concerning the management of tourism in Poland, with particular emphasis on planning. The main purpose was to analyze the issues related to the planning of tourism and recreation in Poland and in this context to show the importance of planning for the proper development of tourism. The research procedure which was applied was mainly the analysis of source materials. With regards to tourism there can be distinguished plans from the sphere of socioeconomic (created at the central, regional and local level and for businesses operating in the field of tourism), and spatial plans (implementedin thewholecountry,provinces and municipalitiesand separately selected for particular areas). Creation of ones and the others is justified. In connection with the fact that tourism plays an important role in the economy of many countries, appropriate management of its development becomes important, and the planning which underlies management often helps to avoid in this regard, the method of trial and errors. It should be stressed that tourism is also a field that uses widely the space, but this space is affected mostly negative by it. Planning, which is the basis for setting targets and ways of their implementation, provides, among others, the possibility to reduce the negative consequences associated with its development.
\end{abstract}

Key words: management, planning, Poland, tourism and recreation.

\section{Introduction}

Tourism plays a significant role in the economy of many countries. The share of tourism economy in Polish GDP in 2009-2010 was constant and was 5.3\% per year. At the same time there can be observed a number of positive and negative consequences of its development. In order to reduce the latter, it is necessary to introduce the proper management of tourism. One of the solutions is proper planning and coordination of tourism development in this regard taken action. An effective tool can be spatial development plans and the incorporation of tourism in the development plans of socio-economic. In areas with a high-rank tourist attractions it makes sense to create separate documents for the development of tourism. This study is focused on the release of current issues concerned with the theme of the Polish example, where since 1989 there have been diametrical changes in the economy that did not avoid the sphere of tourism. In order to investigate the issue it was useful to provide tourism management structure in Poland, and analysis of a series of planning documents related to the development of tourism at local, regional and national levels with an explanation of the merits of their creation. The main purpose was to analyze the issues related to the planning of tourism and recreation in Poland and in this context to show the importance of planning for the proper development of tourism.

Presented subject-matter was partially analyzed by other authors. Issues of organization 
and management of tourism in Poland were considered among other by Butowski (2007), Borzyszkowski (2011). In turn the issues related to the tourism planning (mainly in the planning oftourism development) were analyzed, for example by: Warszyńska, Jackowski(1979), Kowalczyk, Derek (2010). Borzyszkowski (2011) refered to the planning of cultural tourism, and Alejziak (2000) considered programming methodology issues of tourism development on local and regional level. It should be underlined that Poland belongs to countries with long traditions in the elaboration of plans for tourist development, as already in the 30 s of 20th century, this work were led by S. Leszczyki with gathered around him, geographers and planners (Kowalczyk, Derek, 2010, p. 151). This publication relates on the one hand to issues related to the management of tourism in Poland, which constitutes a starting point for further considerations, on the other hand, draws attention to the essential issues of the planning of tourism, which was analyzed from a national, regional and local perspective.

\section{Methodology of Research}

The subject of discussion is a management of tourism and in particular, managing tourism institutions in Poland, and the planning function. Planning understood as formulation of objectives and identification of ways of their implementation over time and in the organizational units is one of the activities involved in the management process. "The management in tourism is a set of activities (involving planning and decision making in the widely understood tourism economy, organizing, directing people) aimed at the tourist resources of the organization (human, material, financial, natural, and information) and used to achieve the objectives of these organization in an efficient and effective way" (Michałowski, Ziółkow ski, 2002, p. 19).

The research procedure uses a set of test methods based primarily on an analysis of the literature and source materials. The main sources were publications, laws and regulations and a series of planning documents generated at different levels, both in terms of planning associated with the economic zone as well as spatial including plans related to the area of socioeconomic and spatial development plans.

\section{Results of Research}

\section{Institutional Aspect of Tourism Management in Poland}

Poland has more than 38 million inhabitants and covers an area of $312679 \mathrm{~km}^{2}$. According to Institute of Tourism, Poland attracted in 2010 over 58 million of foreigners, including about 12.5 million tourists (Arrivals to Poland by quarters, 2011). Projections indicate a further increase in the number of tourists to 14.6 million people in 2015 (Trends and Forecast. Number of arrivals of inbound tourists, 2011). Tourism plays a significant role in the economic development of the country. Its proper development entails the necessity of adequate management. In Poland, the minister responsible for tourism is to the Minister of Sport and Tourism, which operates within the framework established by the Council of Ministers dated on 23 of August 2005 the Ministry of Sport and Tourism. It covers the Political Cabinet of the Minister and 13 organizational units ( 8 departments, including the Department of Tourism, 5 offices). It is generally assumed that the government in relation to tourism has the following functions: coordination, planning, legislation, economic activity, stimulation, socialization, tourism, protection of the public interest (Borzyszkowski, 2011, p. 35). Department of Tourism is responsible for "tourism development programming, for designing legal and economic mechanisms governing tourism, and for supervising tasks related to tourism promotion on the domestic and foreign markets" (Organizational structure, subordinate and supervised units, 2010). The Minister responsible 
PROBLEMS

OF MANAGEMENT

IN THE $21^{\text {st }}$ CENTURY

Volume 3, 2012

38 for tourism supervises the Polish Tourist Organization. One of the objectives of its activities is the promotion of Poland as a country attractive to tourists. The organization has offices in 14 countries around the world (mainly in Europe but also in North America and Asia).

It should be mentioned that the number of activities directly and indirectly affecting the development of tourism is the responsibility of other ministries and central offices. Moreover, in Poland an important role in the development of tourism is the role of local governments. In a country with effect from 1 January 1999, there was implemented radical three levels territorial division of the country to which the units are municipalities, counties and provinces. At the discretion of local provinces there are tourism-related skills such as empowerment of tour leader and tour guides, hotel facilities ranking of the various types and categories, making an entry in the register of tour operators and travel agents together with their control and many other activities. In turn at the county level among competences of local authorities in the field of tourism there may be included for example: conducting a physical cultural institutions, tourism and recreation operating in the county, records, and supervision over the activities and funding associations working in the sphere of physical culture, sports associations, tourist associations established in the county, cooperation in the field of spatial planning and land development in sport, leisure and tourism. The basic unit of local government in Poland is a municipality. Its organs develop tourism, among others through: the development of spatial planning and land use including: sport, leisure and tourism facilities, creating favorable conditions for making business in the sphere of tourism in the municipality, activities to protect the natural environment and cultural heritage.

A huge role in the development of tourism without doubt play economic entities and their associations, universities and entrepreneurs operating educational and non-governmental organizations such as the Polish Country-Touring Society, and others. Summary of strengths and weaknesses of tourism management in Poland are presented in Table 1. To the strong sides in relation to the public sector is considered a long-term strategies, and in case of the private sector weakness is a limited interest in long-term planning. The Polish system of organization and management of tourism is similar to the solutions practiced in most European countries (Borzyszkowski, 2011, p. 130). It is worth emphasizing the role of specialized research institutions conducting research in the field of tourism. An example of such institution is the Institute of Tourism which has acted since 1972, as well as various business units operating within the structures of universities, which in addition to studies dealt with the educational activity (Butowski, 2007, p. 108). Personnel training for tourism is mainly conducted in the secondary schools, universities, or by the way of different kinds of courses and training. From among 455 universities, 66 educated professionals to work in tourism, with over $90 \%$ in tourism and recreation (Ronikier, 2012).

Table 1. Strengths and weaknesses of tourism management by sectors in Poland.

\begin{tabular}{|l|l|l|}
\hline & \multicolumn{1}{|c|}{ Strengths } & \multicolumn{1}{c|}{ Weaknesses } \\
\hline $\begin{array}{l}\text { Public } \\
\text { sector }\end{array}$ & $\begin{array}{l}\text { long-term strategies, } \\
\text { building a positive image of the destina- } \\
\text { tion country, } \\
\text { support instruments for small and medium } \\
\text { enterprises, } \\
\text { stimulation of quality, }\end{array}$ & $\begin{array}{l}\text { lack of an explicit aim while creating new tasks, } \\
\text { limited generation of commercial revenues, } \\
\text { lack of willingness to take risk, } \\
\text { toleration of poor performance, } \\
\text { slowness in decision-making (long procedures), } \\
\text { disbelief in the private sector, }\end{array}$ \\
\hline $\begin{array}{l}\text { Private } \\
\text { sector }\end{array}$ & $\begin{array}{l}\text { Short term tactics } \\
\text { focusing on the economic effect, } \\
\text { PR management skills, } \\
\text { speed of decision making, } \\
\text { entrepreneurship, }\end{array}$ & $\begin{array}{l}\text { lack of concern for public good, } \\
\text { limited interest in long-term planning, } \\
\text { inadequate resources to the partnership, } \\
\text { discouragement and limited trust in all activities undertaken } \\
\text { by the public sector. }\end{array}$ \\
\hline
\end{tabular}

Source: based on Marketingowa strategia Polski w sektorze turystyki na lata 2008-2015, p. 12 


\section{Planning and Tourism (socio-economic zone)}

The basic planning document with strategic character which determines the socio - economic development directions in Poland and at the same time constitutes a reference point for other Government's and developed by local government's strategies is the National Development Strategy for 2007-2015. In this document there was indicated the objective connected with increasing the quality and standard of living of the Polish population (National Development Strategy 2007-2015, p. 10). Its elaboration was important in connection with the objectives fulfillment of the European Union financial support. A number of elements is related to the realization of this goal among which there is mentioned citizen participation in culture and tourism. In terms of tourism itself the leading issues are the "Directions of tourism developing until 2015". This is a government document adopted by the Council of Ministers on 28th of September 2008. In its elaboration took part administration representatives of local government, entrepreneurs, non-governmental organization, academic world and in the direct process of consultation.

In the above mentioned document, it is assumed that tourism development should be subordinated to achieve three general values creating mission of tourism development in Poland. These assumptions are related to tourism as an area synergistic with respect to other, important from the stand point of the country's development goals, building a positive image of Poland, respect for sustainable development and create competitive tourist products (Directions tourism developing until 2015, 2008, p. 25).

It should be emphasized that the activity of the Polish Tourism Organization is a significant instrument of Polish Marketing Strategy in the field of tourism for the years 20082015. This document is important in the development of regional and local documents for the promotion of tourism.

At the level of other territorial subdivisions there are created separate planning documents. According to the Act of 5 June 1998 on Voivodeship Self-government provincial government determines the strategy development of the region. In most cases they is included tourism by the way of determining the directions of development. Furthermore, additional plans are created for the development of tourism in the provinces.

With respect to the Act of 8 March 1990 on Gmina Self-government and the Act of 5 June 1998 on Powiat Self-government, the Local Government does not determine directly the duty of creating and implementing development strategies. However, the requirements for the effective operations enforce local government to reach such kind of instruments. As with the case of provinces so in the relation to counties and municipalities in many of them there was taken into account tourism. There are often elaborated separate plans for the development of tourism, or tourism products. Planning activities also applies to enterprises and institutions associated with the tourist industry

\section{Planning and Tourism (spatial area)}

Principles of spatial policy-making by local authorities and government bodies have been determined mainly in the Act of 27 March 2003 on Spatial Planning and Development. The compound also exhibit other provisions, including some 60 laws and over 100 executive acts, and constitutional law (Polska przestrzeń. Raport o stanie zagospodarowania przestrzennego kraju, 2007, p. 152)

In Poland, the planning system includes three levels of public authority: a national, provincial and municipal. The national level there is prepared the concept of spatial development of the country, which reflects the principles of sustainable development, among others, on the basis of natural, cultural, social and economic conditions. This concept is the act of planning and is the basis for shaping the spatial policy of the state. 
PROBLEMS

OF MANAGEMENT

IN THE $21^{\text {st }}$ CENTURY

Volume 3, 2012

40

Formulation and conduct of regional spatial policy is the responsibility of voivodeship government. Themain instrumentinthis actionis planof spatialdevelopmentofvoivodeship. The document takes into account the determination of regional development strategies, as well as establishment of the concept of spatial development of the country. At local level, the first step is to develop the study of conditions and directions of spatial management of municipality. According to Polish Academy of Sciences report at the end of the 2007, almost all municipalities across the country had municipal studies (Raport o stanie i uwarunkowaniach prac planistycznych w gminach na koniec 2007 roku, 2008, p. 13).

The next steps are intended to produce a local spatial development plan. This plan specifies, inter alia, the principles of environmental protection, nature and cultural landscape, the principle of protection of cultural heritage and modern cultural monuments and principles of modernization, expansion and construction of communication systems and technical infrastructure. At the end of 2007 in Poland, 2192 municipalities had plans for the local municipality in which there were binding 37071 plans (Śleszyński, 2009).

\section{Discussion}

The changes taking place in Poland since 1989 have forced a different perspective on management issues, including tourism management. One of the effects of these changes was to draw attention to the problem of properly prepared plans for tourism development. This in turn is connected with the proper determination of the purpose based on accurately diagnosed layout of future conditions and resources. Analysis of sample planning documents confirmed that on the one hand they play the role of a tool to promote positive change in the field of tourism, on the other hand are they constitute a source of information for entrepreneurs, and generally the whole local community.

Spatial planning focuses on administrative units or their parts, and its aim is to ensure the proper development of individual areas of the country. In the case of tourism development planning in the strictly tourist areas, planning is a superior or at least equal matter, it is for other types of sites, its role is complementary to the other areas of economic and social life, or so secondary (Kowalczyk, Derek, 2010, p. 196)

In a situation where tourism is an area which widely uses the space it is necessary to maintain a balance between the requirements of residents and businesses, tourists and environmental protection. To effectively manage tourism in areas of high-rank tourist attractions makes sense to create separate planning documents for the development of tourism. In the seventies of last century O. Rogalewski insisted that in the areas with the most valuable tourist qualities, the whole economy must be subordinated to its touristic needs and for the other areas of touristic value there must be established specific terms and conditions for coexistence between tourism and other spatial economic activities (Rogalewski, 1974, p. 37). It is also necessary to integrate strict planning at different levels, and extensive cooperation with the local community together with their education. In the case of some countries or regions there is formed a kind of guide of planning for tourism which helps to understand the entities associated with the development of tourism, the role which plays its proper planning and which document needs to be prepared. These issues are widely discussed, with examples of planning activities by Inskeep (1994). It is desirable to create this type of studies in Poland, which would help more to integrate and harmonize the tourist planning system. 


\section{Conclusions}

Planning is the basic function of management. In Poland, the minister responsible for tourism is to the Minister of Sport and Tourism, who also supervises the Polish Tourist Organization. It should be noted that the number of jobs directly and indirectly affecting the development of tourism is the responsibility of other ministries and central offices. Besides, in the field of tourism it is important the role of local governments. The current threelevels territorial division of the country is based on the municipalities, counties and provinces. Created at different levels of decision-making plans are important documents, which on the one hand sets out objectives and directions of development, on the other, organize the development management matters of individual units. Another issues are the issues related to spatial planning. In Poland, the planning system includes three levels of public authority: a national, provincial and municipal. In the spatial plans there are taken into account issues related to tourism. At the same time in areas covered by these kind of plans conflicts arising from the needs of residents of the touristic areas, tourists' needs and requirements and environmental protection are less frequent.

\section{References}

Alejziak, W. (2000). Metodologia programowania rozwoju turystyki na szczeblu lokalnym i regionalnym. In M. Boruszczak [Ed.], Polityka samorzadu terytorialnego $w$ dziedzinie turystyki (pp. 36-49) Sopot: Wyższa Szkoła Turystyki i Hotelarstwa w Sopocie.

Butowski, L. (2007). Organizacja turystyki w Polsce. Lublin: Wydawnictwo Akademickie Wyższej Szkoły Społeczno-Przyrodniczej w Lublinie.

Borzyszkowski, J. (2011). Organizacja i zarządzanie turystyka w Polsce. Warszawa: CeDeWu Sp. z o.o., Wyższa Szkoła Bankowa w Gdańsku.

Borzyszkowski, J. (2011). Turystyka kulturowa $w$ dokumentach planistycznych wybranych krajów europejskich. Retrieved 29/02/2012 from turystykakulturowa.org/pdf/2011_05_01.pdf

Inskeep, E. (1994). National and regional tourism palnning. Methodologies and case studies. London: World Tourism Organisation and Roultledge.

Institute of Tourism. (2011). Arrivals to Poland by quarters. Retrieved 31/01/2012, from http://www. intur.com.pl/itenglish/arrivals.php? $\mathrm{r}=15$

Institute of Tourism (2011). Trends and Forecast. Number of arrivals of inbound tourists. Retrieved 31/01/2012, from http://www.intur.com.pl/itenglish/forecasts.htm\#

Kowalczyk, A., Derek, M. (2010). Zagospodarowanie turystyczne. Warszawa: Wydawnictwo Naukowe PWN.

Michałowski, K., \& Ziółkowski, R. (2002). Zarządzanie turystyką. Białystok: Wydawnictwo Politechniki Białostockiej.

Ministerstwo Budownictwa. (2007). Polska przestrzeń. Raport o stanie zagospodarowania przestrzennego kraju. Warszawa.

Ministry of Regional Development (2006). National Development Strategy 2007-2015. Warszawa: Retrieved 31/01/2012 from http://www.mrr.gov.pl/english/strategies/srk/strony/srk.aspx

Ministry of Sort and Tourism Republic of Poland (2008). Directions for tourism development until 2015. Warszawa. Retrieved 31/01/2012 from http://msport.gov.pl/turystyka

Ministry of Sport and Tourism of the Republic of Poland (2010). Organizational structure, subordinate and supervised units. Retrieved 31/01/2012, from http://msport.gov.pl/en/organizational-structure_subordinate -and-supervised-units- 
PROBLEMS

OF MANAGEMENT

IN THE $21^{\text {st }}$ CENTURY

Volume 3, 2012

42 Napiórkowska, M. (2001). Czy Polska podpisze list otwarty UNWTO i WTTC? Wiadomości Turystyczne, Retrieved 23/02/20011 from http://www.wiadomosciturystyczne.pl/index.php?action=aktualnosc i\&start=aktualnosci\&ID=748

Polska Akademia Nauk Instytut Geografii i Przestrzennego Zagospodarowania im. S. Lszczyckiego (2008). Raport o stanie $i$ uwarunkowaniach prac planistycznych $w$ gminach na koniec 2007 roku. Warszawa: Retrieved 31/01/2012 from http http://www.mi.gov.pl/files/0/1789468/ RAPORTcao2007.pdf

Polska Organizacja Turystyczna (2008). Marketingowa Strategia Polski w sektorze turystyki na lata 2008-2015. Warszawa. Retrieved 31/01/2012 from http://www.polska.travel/files/PDF/Strategia/ index.html

Ronikier, A. (2012). Analiza kształcenia kadr dla potrzeb turystyki. Polska Izba Turystyki. Retrieved 23.02.2012 from http://www.pit.org.pl/index.php?navi=006,001\&id=1586.

Rogalewski, O. (1974). Zagospodarowanie turystyczne. Warszawa: Wydawnictwa Szkolne i pedagogiczne.

Śleszyński, P. (2009). Planowanie przestrzenne w gminie. Retrieved 31/01/2012 from http://samorzad.infor. pl/sektor/zadania/zarzadzanie_nieruchomosciami/artykuly/389047,planowanie_przestrzenne_w_ gminie.html

The Act of 5 June 1998 on Voivodeship Self-government. In: Internetowy System Aktów Prawnych. Retrieved, 31/01/2012 from http://isap.sejm.gov.pl/DetailsServlet?id=WDU19980910576

The Act of 8 March 1990 on Gmina Self-government. In Internetowy System Aktów Prawnych. Retrieved 31/01/2012 from http://isap.sejm.gov.pl/DetailsServlet?id=WDU19900160095

The Act of 5 June 1998 on Powiat Self-government In Internetowy System Aktów Prawnych. Retrieved 31/01/2012 from http://isap.sejm.gov.pl/DetailsServlet?id=WDU19980910578

The Act of 27 March 2003 on Spatial Planning and Development In Internetowy System Aktów Prawnych. Retrieved 31/01/2012 from http://isap.sejm.gov.pl/DetailsServlet?id=WDU20030800717

Warszyńska, J., Jackowski, A. (1979). Podstawy geografii turyzmu. Warszawa: PWN.

Advised by Malgorzata Tyranska, Cracow University of Economics, Poland

Received: February 01, 2012

Accepted: March 06, 2012
Izabela Kapera Dr, Lecturer, Faculty of Tourism and Leisure, University School of Physical Education in Cracow, Al. Jana Pawła II 78, 31-571 Kraków, Poland.

E-mail: lowczowska@poczta.onet.pl

Website: http://www.awf.krakow.pl/index.php/english-pages 